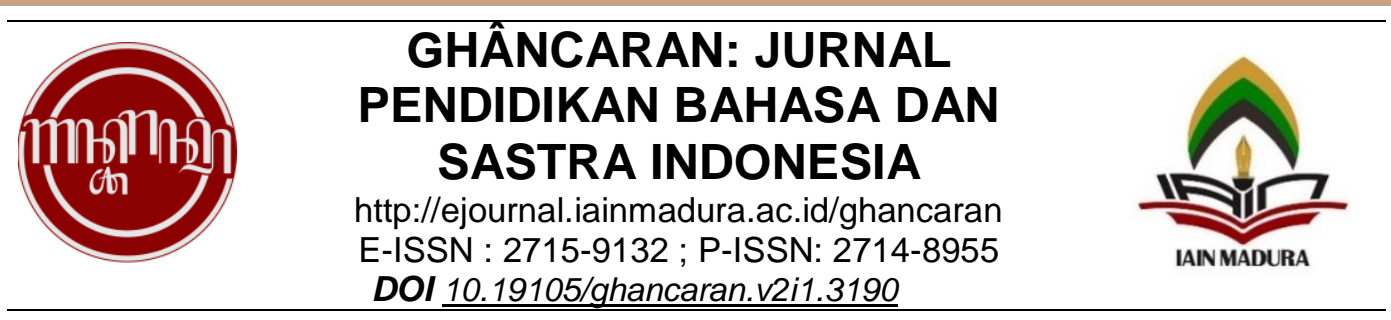

\title{
NARATOR DAN KEBERULANGAN CERITA DALAM FILM "PERFUME THE STORY OF A MURDERER"
}

\author{
Agung Sutrisno* \\ *Universitas Airlangga \\ Alamat surel: sutrisno.agung1989@gmail.com
}

\begin{tabular}{ll}
\hline \hline & Abstract \\
\hline Keywords: & This research article has to describe the role of the narrator and the \\
Narrator, & repetition that occurs in the film "Perfume The Story of A Murderer". \\
naratology, & Material objects in this research article is the film "Perfume The \\
film. & Story of A Murderer". Formal objects in this research article is the \\
& location of the narrator and the frequency contained in film \\
& "Perfume The Story of A Murderer", with narratology theory from \\
& Gerard Ganette. The methods used in this research article is \\
& descriptive qualitative with a structural approach. The results \\
& obtained in this research article indicate that the narrator has a \\
& function to direct the audience to understand the story visually \\
& presented in the film, and the film "Perfume The Story of A \\
& Murderer"raises a recurrence in the telling as the main values in the \\
& film's story. \\
\hline \hline & Abstrak: \\
\hline Kata Kunci: & Artikel penelitian ini memiliki tujuan untuk mendeskripsikan peranan \\
narrator, & narator serta keberulangan yang terjadi dalam film "Perfume The \\
keberulangan, & Story of A Murderer". Objek meterial artikel penelitian ini adalah film \\
naratologi, film. & "Perfume The Story of A Murderer". Objek formal artikel penelitian \\
& ini letak narator dan frekuensi yang terdapat pada film "Perfume \\
The Story of A Murderer" dengan memanfaat teori naratologi dari \\
Gerard Ganette. Metode yang dipakai dalam artikel penelitian ini \\
adalah deskriptif kualitatif dengan pendekatan struktural. Hasil yang \\
diperoleh dalam artikel penelitian ini menunjukkan bahwa narator \\
memiliki fungsi untuk mengarahkan penonton agar memahami \\
cerita secara visual yang disajikan dalam film, dan film "Perfume \\
The Story of A Murderer" memunculkan keberulangan dalam \\
penceritaan yang sebagai yang merupakan nilai-nilai utama dalam \\
cerita film tersebut.
\end{tabular}

\section{PENDAHULUAN}

Telaah mengenai film sebagai produk sastra sangatlah masih terbatas. Para kritikus banyak melihat film dari segi pemeranan dan produksi namun masih mengabaikan bagaimana seorang director ataupun sutradara mengarahkan cerita untuk merebut perhatian penonton. Melihat lebih jauh sastra dan film para formalis Rusia menyebut penanda cerita sebagai fabula dan petanda cerita sebagai sjuzhet. Menurut (Bramantio, 2010: 24) Fabula merupakan cara menceritakan dari cerita secara berurutan temporal kausal. Sedangkan sjuzhet adalah cerita yang dihadapi oleh pembaca. 
Genette (1980: 27) berpendapat terdapat tiga hal mengenai teks naratif yaitu; story, narrative, dan narrating. Story adalah petanda atau isi teks naratif; narrative adalah penanda, pernyataan, wacana, atau teks naratif itu sendiri; sedangkan narrating adalah kegiatan yang menghasilkan teks naratif. Narrative atau sjuzhet atau fiction kadang juga disebut diegesis atau discourse. Dalam penelitian ini, untuk seterusnya narrative atau narasi disebut penceritaan dan story disebut cerita.

Sebuah film memiliki cara tersendiri dalam menyajikan cerita dalam filmnya sehingga menimbulkan efek tertentu dalam penceritaannya. Cara paling umum dan sering kita jumpai dalam kebanyakan film adalah dengan memperkenalkan tokoh utama yang berperan dalam film. Sedangkan gaya penceritaan yang paling umum ditemukan dimulai dari awal cerita, kemudian bergerak ke perkenalan konflik, baru kemudian ke akhir cerita. Strategi lainnya adalah seperti memunculkan fragmen yang sama berulangulang untuk menunjukkan retrospeksi, menghentikan cerita (jeda), melompati rentang waktu tertentu dan langsung beralih ke waktu selanjutnya (elipsis), dan pengaturan pemunculan narator.

Narasi atau penceritaan secara umum diartikan sebagai sarana pengarang untuk menggali berbagai kemungkinan estetik. Namun dalam sebuah film, narasi bisa diartikan sebagai sarana seorang narator untuk membuka atau memberikan gambaran bagaimana jalan cerita dari sebuah film. Paparan atau penggambaran (visualisasi) terus berubah dari sebelumnya dan berkembang bertujuan untuk menunjukkan bahwa eksplorasi dalam narasi penting diperhatikan. Bila dalam kemungkinan estetik baru dalam narasi tersebut ditemukan keunggulan-keunggulan, kemungkinan tersebut dapat menjadi satu genre baru.

Dalam film "Perfume The Story og A Murderer" memiliki narasi yang begiru kuat dan menarik untuk dikaji. Narasi merupakan teknik memahami penceritaan. Narasi juga digunakan untuk memahami peristiwa yang diceritakan (Rahayu, 2020: 2). Memahami peritiwa yang terjadi di dalam film dapat membantu penonton memahami cerita. Namun tidak semua narasi mampu membantu penonton memahami film, bisa jadi narasi yang dihasilkan menyulitkan penonton film dalam menikmati film dengan baik. Ilmu Naratologi hadir sebagai pengurai kesulitan dalam memahami alur penceritaan yang dicari, bagaimana pemecahan cerita, dan cara memahaminya. Dalam teknik penceritaan film "Perfume The Story of A Murderer" memiliki sesuatu yang unik. Film ini lebih didominasi kehadiran sosok narator yang menceritakan sosok tokoh Jean Baptiste Grenouille. Jean Baptiste Grenouille dalam film "Perfume The Story of A Murderer" yang merupakan adaptasi dari novel "Das Perfume" karya Patrick Suskind ini, adalah seorang pemuda yang mencari pembenaran siapakah dirinya serta tujuan hidupnya.

Film tersebut mengambil setting pada masa abad pertengahan di Perancis. Film yang bercerita di mana masyarakat Perancis masih dilingkupi paham feodalisme yang mengusai setiap aspek kehidupan. Sehingga, menimbulkan kesenjangan yang amat dalam antara kaum proletar dan kaum bangsawan. Dalam ulasan singkat film oleh Risma dalam blognya (Risma, 2009) mengisahkan perjalanan hidup Jean Baptiste Grenouille yang lahir di pasar yang amat kumuh. Jean Baptiste Grenouille dilahirkan dengan istimewa, memiliki indra penciuman yang luar biasa tajam melebihi indra penciuman manusia normal. la mampu memilah-milah seluruh bau yang ada bahkan diceritakan tak ada kata yang mampu menampung setiap bau yang berhasil dicium Grenouille. Pada suatu ketika ada sesuatu hal yang membawa Grenouille harus pergi dari tempat penampungan dan bekerja ditempat penyamakan kulit. Dari sinilah awal mula Grenouille dapat menyium aroma yang lebih banyak lagi. Pada suatu hari situasi membawa dia untuk bekerja di pusat kota Paris, dan dari sanalah ia mengetahui "aroma tubuh perawan", yang membawa dia ke dalam suatu kenikmatan yang amat sangat, dan menjadi adiktif karenanya. Di Parislah dia melakukan pembunuhan pertamanya hanya 
untuk mengambil aroma tubuh yang dimiliki seorang gadis perawan. Cerita dan sepak terjang Jean Baptiste Grenouille dalam evolusi dirinya yang dari seorang pemuda biasa menjadi pembunuh yang berdarah dingin akibat obsesinya yang ingin menciptakan "parfum sejati" yang baunya berasal dari aroma tubuh perempuan (Sitohang, 2008).

Selain itu dalam film ini dari awal penceritaanya sampai ke tengah penceritaan terjadi peristiwa-peristiwa yang berulang seperti kematian tokoh yang memiliki hubungan kedekatan atau yang menampung tokoh Jean Baptiste Grenouille. Selain itu kemunculan narator sebagai tokoh yang yang serba tahu akan perasaan, hal yang difikirkan tokoh utama dan tokoh lain dalam film. Permasalahan tersebut berada di tataran struktur penceritaan atau narasi dalam film "Perfume The Story of A Murderer". Struktur penceritaan tersebut harus dipaparkan untuk memecahkan permasalahan tersebut. Teori yang bisa digunakan untuk membedah struktur penceritaan adalah teori naratologi. Genette berpendapat, cerita dan cara menceritakan bisa diketahui melalui perantara penceritaan (Genette, 1980:29). Untuk mengetahui cerita dan bagaimana cerita itu diceritakan, satu-satunya cara adalah dengan memeriksa penceritaannya. Naratologi menjadi teori yang mengajukan metode untuk mengkaji hubungan antara penceritaan dan cerita, penceritaan dan cara menceritakan, serta cerita dan cara menceritakan.

\section{METODE}

Penelitian ini menggunakan metode deskriptif kualitatif dan memanfaatkan pendekatan struktural sebagai metode analisis. Pemanfaat metode deskriptif kualitatif dipandang relevan karena untuk menguraikan data berupa kata, kalimat, yang berupa tuturan dari tokoh-tokoh film dibutuhkan uraian secara deskritif untuk menganalisis dan menjabarkan hasil dan pembahasan. Pendekatan struktural digunakan untuk menganalisis secara mendalam agar memperoleh kritik yang relevan mengenai isi dari cerita film "Perfume The Story of A Murderer". Bramatio (2010:26) menjelaskan bahwa Analisis struktural bukan hanya menjumlahkan unsur-unsur dari produk sastra, namun menekankan pada bagaimana cara menganalisis unsur-unsur produk sastra tersebut.

Teknik analisis data yang digunakan dalam penelitian ini menggunakan teknik hermeneutika, yang memiliki tahapan, yaitu membaca merupakan proses pertama dalam penelitian membaca dipahami sebagai menyimak. Selanjutnya, mencatat sebagai tahapan yang dilakukan bersamaan dengan menyimak film "Perfume The Story of $A$ Murderer" untuk mempermudah mengingat, selanjutnya mengorganisasikan catatan dari menyimak film tersebut dalam suatu sistem membantu dalam proses untuk memaknai, dan tahapan yang terakhir menganalisis data dengan sesuai fokus dalam penelitian.

\section{HASIL DAN PEMBAHASAN}

Dalam menganalisis sebuah cerita dalam film menggunakan pokok pemikiran Genette mengenai tata. Setiap cerita maupun penceritaan memiliki satuan-satuan cerita yang sama. Perbedaannya hanyalah pada tata urutannya. Untuk menentukan tata alur cerita dan penceritaan pada film "Perfume The Story of A Murderer" disusun sekuen atau satuan-satuan cerita terlebih dahulu.

Sekuen tersebut kemudian akan dipilih peristiwa-peristiwa yang mempunyai hubungan satu sama lain yang terikat, yang disebut dengan fungsi utama untuk memperoleh sebuah kerangka cerita. film "Perfume The Story of A Murderer" terbagi menjadi 50 sekuen dan 13 cerita utama.

Dalam kronologi fungsi utama disusun sesuai dengan urutan penceritaan, serta akan diidentifikasi urutannya dalam cerita. Oleh karena film dimulai dari tengah cerita yang mengisahkan ketika tokoh Grenouille ketika ditangkap di Grasse dan menjadikan bahwa penangkapannya sebagai cara masuk dalam penceritaan film ini sendiri. Serta 
peristiwa penangkapannya tersebut berperan sebagai akhir dari cerita film "Perfume The Story of A Murderer", maka akan disusun tabel sebagai berikut;

\begin{tabular}{|c|c|}
\hline Sekuen & Cerita Utama \\
\hline $1,45,46$ & $\begin{array}{l}\text { Grenoullie diinterograsi, dan keeadaannya } \\
\text { dipenjara }\end{array}$ \\
\hline 2 & Kelahiran Grenoullie dan nasib ibunya \\
\hline 3,4 & $\begin{array}{l}\text { Grenoullie dibawa ke panti dan keadaannya di } \\
\text { panti }\end{array}$ \\
\hline $6,7,8,9$ & $\begin{array}{l}\text { Grenoullie dibawa ke tempat penyamakan dan } \\
\text { peristiwa ketika Grenoullie menemukan banyak } \\
\text { aroma yang dia inginkan }\end{array}$ \\
\hline 8 & $\begin{array}{llll}\begin{array}{l}\text { Pembunuhan } \\
\text { Grenoullie }\end{array} & \text { pertama yang dilakukan } \\
\end{array}$ \\
\hline $8,10,11,12,13,14,15$ & $\begin{array}{l}\text { Grenoullie dan tempat parfum, pertemuan } \\
\text { dengan Baldini master parfum, belajar } \\
\text { mempertahan aroma, dan bagaimana membuat } \\
\text { parfum }\end{array}$ \\
\hline $17,18,19,20,21$ & Grenoullie pergi ke Grasse \\
\hline $22,24,26,42,43,44$ & $\begin{array}{l}\text { Grenoullie } \quad \text { menemukan } \\
\text { mempertahankan dan menyimpan aroma dan } \\
\text { pembuatan parfum }\end{array}$ \\
\hline $\begin{array}{l}23,24,25,27,28,29,30,31,33,34,38, \\
42,43\end{array}$ & $\begin{array}{l}\text { Grenoullie melakukan pembunuhan untuk } \\
\text { obsesinya akan parfum }\end{array}$ \\
\hline 43,44 & Korban ke 13 dan penangkapannya \\
\hline $1,45,46$ & $\begin{array}{l}\text { Grenoullie diinterograsi, dan keeadaannya } \\
\text { dipenjara }\end{array}$ \\
\hline 47 & $\begin{array}{l}\text { Hari eksekusi Grenoullie dan eksekusi } \\
\text { pengganti Drout sebagai pengganti Grenoullie }\end{array}$ \\
\hline $48,49,50$ & $\begin{array}{l}\text { Grenoullie kembali ke paris dan kematiannya, } \\
\text { akhir film }\end{array}$ \\
\hline
\end{tabular}

Tabel 1. Sekuen Film "Perfume The Story of A Murderer"

\section{Posisi Narator dalam Film "Perfume The Story of A Murderer"}

Pembahasan dari posisi dari narator menggunakan pokok pemikiran Genette mengenai modus dan tutur. Permasalahan narator dalam film ini adalah tidak adanya wujud dari narator yang hadir dalam cerita film "Perfume The Story of A Murderer" terdapat kemungkinan dan pernyataan dari peneliti bahwa narator dalam film ini sengaja tidak dihadirkan dalam wujud tokoh. Namun narator dihadirkan dalam bentuk sound yang selalu hadir dalam cerita dan menunjukkan bahwa cerita dari film akan menuju ke arah mana, narator dalam film ini bisa disebut juga sebagai pendongeng merujuk pada prolog pertama ketika film berlangsung. Pada menit dan prolog sebagai berikut;

00:03:43, 196 --> 00:03:45,365

Pada abad ke-18 perancis...

00:03:45,657 --> 00:03:47,492

hiduplah salah seorang pria

yang paling berbakat

00:03:47,659 --> 00:03:50,662

dan tokoh terkenal pada masanya.

00:03:52,038 --> 00:03:54,624

Namanya

Jean-Baptiste Grenouille.
00:04:36,499 --> 00:04:39,294

Tentu saja, bau busuk yang paling buruk terdapat di Paris...

00:04:39,461 --> 00:04:42,047

untuk Paris yang merupakan kota terbesar di Eropa.

00:04:42,964 --> 00:04:46,634

Dan terdapat daerah di Paris di mana

tak ada bau busuk yang jauh lebih busuk...

00:04:46,801 --> 00:04:48,845

daripada pasar ikan di kota. 
00:03:55,834 --> 00:03:58,253

Dan jika namanya telah dilupakan hari ini, itu karena ...

00:03:58,670 --> 00:04:02,841

bahwa seluruh ambisinya

ditutup-tutupi oleh sebuah kekuasaan...

00:04:03,008 --> 00:04:05,510

sehingga tak meninggalkan jejak dalam sejarah:

00:04:10,598 --> 00:04:13,393

bagaikan sekilas aroma dunia.

00:04:27,782 --> 00:04:29,451

Pada periode yang kita bicarakan...

00:04:29,617 --> 00:04:32,162

terdapat penguasa di kota-kota

yang berbau busuk,

00:04:32,329 --> 00:04:35,081

yang sukar dibayangkan oleh

manusia modern kita
00:04:50,805 --> 00:04:53,224

Ini dia.

Aku akan mengambil kotak lain.

00:04:54,726 --> 00:04:58,772

Di sinilah kemudian,

pada tempat yang paling busuk di seluruh kota...

00:04:59,022 --> 00:05:00,857

Jean-Baptiste Grenouille

00:05:01,024 --> 00:05:03,777

lahir ...

pada tanggal 17 Juli 1738.

00:05:28,885 --> 00:05:31,054

Ini merupakan persalinan yang kelima ibunya.

00:05:31,221 --> 00:05:33,807

Semua persalinannya dilakukan di sini, di bawah kedai ikannya.

00:05:33,973 --> 00:05:37,018

$<i>d a n$ semua yang telah dilahirkan,

atau gagal dilahirkan,</i>

Narator dalam film ini juga bisa dilihat sebagai orang yang serba tahu, dalam melacak posisi narator digunakanlah dua perangkat naratologi, yaitu perspektif dan tutur. Secara sederhana, perspektif adalah tentang siapa yang memandang, sedang tutur adalah persoalan tentang siapa yang berbicara. Dalam membaca posisi narator lewat perspektif terdapat vokalisasi. Dari penjabaran di atas jelas terlihat bahwa posisi narator di film ini merupakan tokoh yang serba tahu.

Setelah mengetahui posisi narator, yang akan dicari kemudian adalah keberadaan narator dalam penceritaan. Untuk itu, digunakan perangkat naratologi lainnya, yaitu tutur. Untuk mencari keberadaan narator, digunakan aspek person dalam tutur. Berbeda dengan karya sastra yang menggunakan sudut pandang orang ketiga serba tahu yang bisa dihadirkan dalam cerita akan tetapi film "Perfume The Story of A Murderer", benar-benar memosisikan narator sebagai narator yang kehadirannya tidak dihadirkan dalam wujud tokoh dalam cerita dengan kata lain narator dalam film ini mengacu pada pembuat film atau penulis cerita film (author-narrator), pengarang implisit (implied author) yang berada di luar tokoh-tokoh film "Perfume The Story of A Murderer".

\section{Keberulangan yang Terjadi dalam Film Perfume The Story of A Murderer}

Frekuensi dalam naratologi mengkaji hubungan perulangan antara cerita dan penceritaan. Pada hakikatnya, sesuatu hal bisa terjadi berulang kali. Namun, yang terulang bukanlah kejadian yang sama persis, melainkan kejadian yang identik. Begitu juga dengan penuturan cerita. Sebuah cerita bisa dituturkan hanya satu kali atau berulang kali dalam penceritaannya.

Frekuensi kejadian dalam cerita dan dalam penceritaaan dapat diidentifikasi menjadi empat jenis yaitu: 1) menceritakan sekali apa yang terjadi sekali; 2) menceritakan sebuah situasi berapa kali dan apa yang terjadi berapa kali; 3) menceritakan situasi dengan apa yang terjadi sekali; dan 4) menceritakan sekali apa, atau menceritakan dalam satu waktu, yang terjadi situasi. Jenis pertama dan kedua disebut penceritaan singulatif (singulative narrative), jenis ketiga disebut penceritaan 
berulang (repeating narrative), dan jenis keempat disebut penceritaan iteratif (iterative narrative).

Hal yang menjadi perhatian di sini adalah (repeating narrative) keberulangan cerita. Dalam film "Perfume The Story of A Murderer" keberulangan cerita terjadi pada hal-hal yang melingkupi tokoh utama Grenouille, Grenouille yang dijual, dari pengasuh, dijual ke bos penyamakan kulit, dijual ke bos pembuat parfum misalnya. Menunjukkan bahwa keberulangan bukan berarti merupakan hal yang memberikan kebosanan akan tetapi dengan keberulangan tersebut akan menambah nilai estetis dari sebuah film, tidak hanya itu dengan keberulangan yang terjadi author ingin memberikan suatu pesan yang ingin ditegaskan. Keberulangan dalam film Perfume The Story of A Murderer dapat dilihat dalam tabel dibawah ini;

\begin{tabular}{c|l}
\hline \multicolumn{1}{c|}{ Sekuen } & \multicolumn{1}{c}{ Deskripsi Cerita } \\
\hline Sekuen 2 & $\begin{array}{l}\text { Begitu lahir, Grenouille sudah mengantar ibunya ke tiang gantungan karena } \\
\text { percobaan pembunuhan. }\end{array}$ \\
\hline Sekuen 3 & $\begin{array}{l}\text { pemilik panti itu membayar sejumlah uang untuk mendapatkan anak-anak } \\
\text { termasuk Grenouille }\end{array}$ \\
\hline Sekuen 6 & $\begin{array}{l}\text { ibu asuhnya menjualnya ke tempat penyamakan kulit di pinggiran kota. la } \\
\text { dihargai murah, dan uangnya langsung lenyap karena ibu asuhnya dirampok } \\
\text { dan di bunuh, bahkan sebelum jauh dari tempat penyamakan kulit itu. }\end{array}$ \\
\hline Sekuen 11 & $\begin{array}{l}\text { Baldini memutuskan untuk membeli Grenouille di tempat penyamakan kulit. } \\
\text { Harganya jauh lebih mahal daripada saat ia dijual dulu. Tentu saja majikannya } \\
\text { senang sekali. Grenouille yang menguping pembicaraan mereka, tersenyum } \\
\text { puas. Majikannya mabuk-mabukan dengan uang yang banyak itu, hingga ia } \\
\text { tertabrak kereta dan mati. }\end{array}$ \\
\hline Sekuen 17 & $\begin{array}{l}\text { Baldini tidur sambil memeluk buku formula hasil karya Grenouille, dan tak } \\
\text { pernah terbangun lagi. Karena, gedung tempat ia tinggal sekaligus tokonya, } \\
\text { roboh, hancur rata dengan tanah, dengan Baldini di dalamnya. }\end{array}$ \\
\hline
\end{tabular}

Tabel 2. Sekuen dan Diskripsi Film "Perfume The Story of A Murderer"

Dari tabel di atas dapat kita lihat terjadi keberulangan yang berkaitan dengan tokoh Grenouille, dengan tokoh-tokoh yang memiliki hubungan kedekatan dengan Grenouille. Ketika tokoh yang memiliki hubungan dengan Grenouille, seperti ibunya, ibu asuhnya, bos di penyamakan, sampai pada Baldini mengalami nasib yang serupa yaitu kematian ketika tokoh-tokoh tersebut meninggalkan atupun ditinggalkan oleh Grenouille.

Hal ini menunjukkan bahwa tokoh Grenouille dilingkupi dengan kemalangan, dia tidak pernah dihargai sebagai manusia seperti pada umumnya, namun tidak lebih sebagai budak. Disamping itu hal ini juga menegaskan bahwa Grenouille sendiri diibaratkan sebagi tokoh pembawa maut dengan kematian-kematian yang mewarnai cerita film Perfume The Story of A Murderer.

\section{SIMPULAN}

Dari pembahasan di atas bahwa dalam film "Perfume The Story of A Murderer" memiliki alur yang diawali dengan flasback ke belakang berawal dari akhir-akhir cerita dan kembali pada tokoh Grenoullie lahir sampai pada ending tokoh Grenoullie mati. Tak hanya dengan alur yang cukup menarik dalam film "Perfume The Story of A Murderer" ini dihadirkan dengan kehadiran narator yang muncul dalam setiap cerita, narator yang ada dalam film ini bisa dikatakan tidak benar-benar hadir dalam wujud tokoh namun dia diwujudkan sebagai sosok yang berada diluar cerita film itu sendiri. Narator tersebut memiliki peranan fungsi sebagai pembatas penonton untuk memahami cerita secara visual yang dihadirkan. Hal ini menunjukkan bahwa narator yang hadir dalam cerita novel aslinya yaitu "Das Perfume" yang membawa pembaca berfantasi sebebasnya amatlah berbeda dengan narator pada film "Perfume The Story of A Murderer" yang 
memberikan batasan pada interpretasi yang disajikan secara visual dalam film. Terakhir dalam film "Perfume The Story of A Murderer" juga terdapat banyak keberulangan dalam ceritanya hal ini tidak malah menunjukkan bahwa film ini terkesan monoton atau membosankan, disamping itu keberulangan cerita tersebut juga memberikan kesan bahwa ada sesuatu hal yang ingin ditegaskan yaitu nilai-nilai penting yang terdapat pada film tersebut. Nilai tersebut dihadirkan dengan kisah bahwa manusia memiliki tidak selalu beruntung serta banyak jalan untuk mengubah jalan hidup.

\section{DAFTAR RUJUKAN}

Bramantio. (2010). Metafiksionalitas Cala Ibi: Novel yang Bercerita dan Menulis tentang Dirinya Sendiri. In Z. Hae (Ed.), Dari Zaman Citra ke Metafiksi: Bungam Rampai Telaah Sastra DKJ (pp. 9-128). KPG.

Budianta, M. (2003). Membaca Sastra (Pengantar Memahami Sastra untuk Perguruan Tinggi) (Cetakan ke). Indonesia Tera.

Culler, J. D. (2006). Literary Theory: a Very Short Introduction. Oxford University Press.

Genette, G. (1980). Narrative Discourse An Essay In Method (J. E. Lewin (ed.)). Cornell University Press.

Miller, J. H. (2011). On Literature: Aspek Kajian Sastra (B. A. Ismayasari (ed.)). Jalasutra.

Rahayu, T. (2020). Durasi Naratif pada Novel Merindu Baginda Nabi Karya Habiburrahman El Shirazy (Kajian Naratologi). Jurnal Pena Indonesia, Volume 6, 111. https://doi.org/10.26740/jpi.v6n1.p1-11

Ricoeur, P. (1991). A Ricoeur Reader: Reflection and Imagination (M. J. Valdes (ed.)). University of Toronto Press.

Risma. (2009). Perfume: The Story Of Murderer. Blog. http://ceritafilmrisma.blogspot.com/2009/09/perfume-story-of-murderer.html

Saryono, D. (2009). Dasar Apresiasi Sastra. Elmatera Publishing.

Sitohang, H. (2008). Id, Ego and Superego Analysis of Jean Baptiste Grenouille Character in Perfume by Patrick Suskind.

Suryajaya, M. (2014). Seniman dan Estetikanya: Menyola Sejarah Estetika, Sejarah Seni Rupa dan Anti-Estetika Badiou (Guru-Guru Muda). 